\title{
DUKUNGAN KELUARGA DAN TINGKAT KEMAMPUAN PERAWATAN DIRI PADA ORANG DENGAN GANGGUAN JIWA (ODGJ)
}

\author{
Wardiyah Daulay ${ }^{1}$, Rinaldi Ginting ${ }^{2}$ \\ ${ }^{1}$ Fakultas Keperawatan, Universitas Sumatera Utara, Indonesia \\ ${ }^{2}$ Fakultas Keperawatan, Universitas Sumatera Utara, Indonesia \\ Email: wardiyah.daulay@usu.ac.id
}

\begin{abstract}
Abstrak
Latar Belakang: Dukungan keluarga merupakan hal yang sangat penting untuk meningkatkan kemampuan perawatan diri pada orang denggan gangguan jiwa meliputi : dukungan emosional, dukungan informasional, dukungan instrumental dan dukungan penilaian dan untuk tingkat kemampuan perawatan diri meliputi : mandi , berpakaian, makan dan BAB/BAK. Desain penelitian ini kuanttaif dengan metode korelasional. Tujuan: Penelitian bertujuan untuk mengetahui hubungan dukungan keluarga dengan tingkat kemampuan perawatan diri ODGJ di Medan Sunggal. Metode: Jumlah sampel sebanyak 18 responden dengan teknik purposive sampling. Alat ukur yang digunakan kuesioner. Hasil: Hasil penelitian menunjukkan dukungan keluarga yang di terima responden sebagian besar mendapatkan dukungan keluarga yang baik sebanyak 12 orang $(66,7 \%)$ yang cukup sebanyak 6 orang $(33,3 \%)$ dan mayoritas tingkat kemampuan perawatan diri yang di dapatkan yakni membutuhkan peralatan atau alat bantu sebanyak 9 orang (50\%). Hasil uji Spearmen terdapat hubungan antara dukungan keluarga dengan tingkat kemampuan perawatan diri pada orang dengan gangguan jiwa di Medan Sunggal yaitu nilai $p=0,03(<0,05)$ dengan kekuatan hubungannya kuat dan arah hubungan positif yaitu nilai $r=0,664$. Kesimpulan: Hasil penelitian ini menunjukkan bahwa semakin tinggi dukungan keluarga maka tingkat kemampuan perawatan diri ODGJ juga semakin meningkat. Diharapkan keluarga dapat memberikan dukungan keluarga yang baik untuk meningkatkan kemampuan perawatan diri orang dengan gangguan jiwa (ODGJ). Saran: Saran yang terdapat pada penelitian ini adalah diharapkan agar dapat menggunakan penelitian ini sebagai acuan untuk menambah wawasan dan memperluas kajian tentang dukungan keluarga yang meliputi dukungan emosional, informasional, instrumental, penilaian dan tingkat kemampuan perawatan diri ODGJ yang meliputi mandi, berpakaian, makan dan eliminasi sehingga dapat meningkatkan penyuluhan atau pendidikan kesehatan secara integral kepada masyarakat.
\end{abstract}

Kata kunci : Dukungan Keluarga, Tingkat Kemampuan Perawatan Diri, Orang Dengan Gangguan Jiwa (ODGJ). 


\begin{abstract}
Background: Family support is very important in increasing in the capacity to do self-care in ODGJ (person with mental disorder) which includes emotional support, informational support, instrumental support, and assessment support while the level of self-care includes bathing, dressing, eathing, and defecating and urinating. Aim: The research used quantitative correlation method. Its objective was to find out the correlation between family support and the capacity to do self-care in ODGJ in Medan Sunggal. Method: The samples were 18 respondents, taken by using purposive sampling technique. The research instrument was questionnaire. Result: The result of the research showed that 12 respondents (66.7\%) had good family support, 6 respondents $(33,3 \%)$ had adequate family support, and 9 respondents (50\%) needed accessories for their self-care. The result of Spearman test showed that there was the positive and significant correlation between family support and the capacity to do self-care in ODGJ in Medan Sunggal at p-value=0.03 ( $p<0.05)$ and $r=0.664$. Conclusions: The result of the reseach showed that the higher the level of family support was, the higher the level of self care in the ODGJ. It is recommended that families provide their support well to increase the self-care of the ODGJ. Suggestion: This reseach was expected to add the insight and broaden their reseaches on includes emotional support, informational support, instrumental support, and assessment support, and the capacity of ODGJ's self-care which included bathing, dressing, eathing, and eliminating, in order to increase people's integral counseling or health education.
\end{abstract}

Keywords: Family support, Level of self-care capacity, ODGJ (person with Mental Disorder

\title{
Pendahuluan
}

Orang dengan gangguan jiwa (ODGJ) adalah seseorang yang mengalami gangguan dalam pikiran, perilaku serta perasaan yang termanifestasi dalam bentuk kumpulan - kumpulan gejala atau perubahan pada perilaku yang bermakna, serta bisa juga menyebabkan seseorang tersebut menderita dan mendapatkan hambatan untuk menjalankan fungsinya sebagai manusia (Undang-Undang Kesehatan Jiwa, 2014).

Data Riskesdas 2018 memunjukkan prevalensi ganggunan mental emosional yang ditunjukkan dengan gejala-gejala depresi dan kecemasan untuk usia 15 tahun ke atas mencapai sekitar $6.1 \%$ dari jumlah penduduk Indonesia. Sedangkan prevalensi gangguan jiwa berat, seperti skizofrenia mencapai sekitar 400.000 orang atau sebanyak 1,7 per 1.000 penduduk. Dan dari hasil riset kesehatan dasar yang di lakukan oleh Kementerian Kesehatan tahun 2010 terdapat 70\% ODGJ datang ke rumah sakit 
jiwa memiliki kondisi yang tidak terawat atau mengalami defisit perawatan diri seperti pakaian kotor, aroma tubuh yang tidak sedap, rambut acak-acakan dan mengalami gangguan pada kulit.

Prevalensi penderita gangguan jiwa di Sumatera Utara terus mengalami peningkatan dalam jangka waktu selama 2014. Hal ini terbukti dari data pasien rawat jalan dan rawat inap di Rumah Sakit Jiwa (RSJ) Daerah Provinsi Sumatera Utara. Berdasarkan data yang didapatkan, pada tahun 2014 pasien yang berkunjung di RSJ Daerah Provsu di Jalan Tali Air No 21 Medan sebanyak 13.015. Dari jumlah 13.015 pasien yang berkunjung dengan rinciannya adalah 11.683 pasien rawat jalan dan rawat inap sebanyak 1.332 pasien. Dari jumlah data tersebut memperlihatkan kenaikan yang sangat drastis dari jumlah pasien di banding tahun 2013, hanya terdapat 7.907 pasien saja, yakni total dari 7.313 pasien rawat jalan dan 594 pasien rawat inap. Artinya, terjadi peningkatan 100 persen (JPNN, 2015). Dan di Kecamatan Medan Sunggal berdasarkan data ODGJ (orang dengan gangguan jiwa) di Wilayah Binaan Puskesmas Sunggal Kecamatan Medan Sunggal bulan Mei 2019 terdapat sebanyak 45 orang mengalami ODGJ dengan rentang usia dari 20 sampai 81 tahun.

Keluarga mempunyai tanggung jawab untuk melakukan perawatan pada ODGJ, karena keluarga yang paling sering berhubungan ataupun kontak langsung dengan ODGJ, keluarga juga di anggap paling paham mengenai kondisi anggota keluarganya, dan keluarga adalah pemberi perawatan yang paling utama untuk mencapai pemenuhan kebutuhan dasar dan mengoptimalkan ketenangan jiwa bagi ODGJ yang membutuhkan waktu yang sangat lama dalam terapi penyembuhan ODGJ (Lestari et al, 2014).

Pemahaman keluarga dalam merawat ODGJ masih belum tepat sehingga menimbulkan sikap yang negatif terhadap pasien. Sikap negatif yang diberikan keluarga kepada ODGJ bisa dilihat dari pendapatnya bahwa penyakit yang terjadi pada ODGJ adalah penyakit menetap ataupun penyakit yang tidak dapat disembuhkan sehingga keluarga lebih sering membiarkan pasien asalkan tidak mengganggu. Keluarga juga mengganggap bahwa gejala yang timbul pada pasien ODGJ merupakan hal yang biasa karena pasien adalah penderita gangguan jiwa. Hampir semua keluarga berpendapat bahwa pasien ODGJ hanya bisa menjadi beban bagi keluarga karena tidak memiliki kemampuan dalam merawat diri sendiri (Marfuah, D; Noviyanti, RD, 2017). Oleh karena itu, ODGJ sangat membutuhkan dukungan yang besar dari keluarga, karena keluarga yang paling dekat dengan pasien, dan dengan diberikannya dukungan kepada pasien ODGJ, maka pasien ODGJ tidak lagi mengalami defisit perawatan diri dan dapat menjalankan kehidupannya dengan mandiri (Kemenkes, 2010).

\section{Metode Penelitian}

Desain penelitian yang di lakukan pada penelitian ini adalah penelitian kuantitatif dengan metode korelasional yang bertujuan untuk mengkaji apakah terdapat hubungan antara variabel, jumlah populasi di Medan Sunggal adalah 45 ODGJ, penelitian ini menggunakan teknik Purposive sampling sesuai dengan kriteria inklusi: ODGJ bersedia menjadi responden, bersedia mengisi kuesioner dengan Google formulir dan dapat di bantu oleh keluarga yang merawat dengan catatan harus sesuai dengan yang dirasakan atau yang dialami oleh ODGJ, memiliki applikasi 
Whatsapp, dalam keadaan sehat dan dapat membaca denggan menggunakan Handphone.

Uji validitas instrument dilakukan oleh Perawat Keperawatan Jiwa di Rumah Sakit Jiwa Prof. Dr.M. Ildrem dan dan hasil uji reliabilitas dari instrument penelitian ini adalah hasil instrument dukungan keluarga telah didapatkan hasil reliabilitasnya yaitu nilai alpha sebesar 0,984 dan instrument tersebut dapat di katakan sudah reliable, serta untuk istrumen tingkat kemampuan perawatan diri adapun hasil nilai alpha yang di peroleh adalah 0,914 sehingga intrumen tersebut dapat di katakan telah reliable.

Izin penelitian dari pimpinan Fakultas Keperawatan Universitas Sumatera Utara, Pemerintah Kota Medan Badan Penelitian Dan Pengembangan, Dinas Kesehatan Kota Medan dan Persetujuan dari Komisi Etik Penelitian Kesehatan F.Kep USU.

\section{Hasil}

Hasil penelitian pada tabel 1. Menunjukkan karakteristik responden dimana hasil penelitian dari 18 responden ditemukan bahwa sebagian besar ODGJ berumur 20-40 tahun yaitu sebanyak 8 orang $(44,4 \%)$, dan berusia 41-60 tahun sebanyak 8 orang $(44,4 \%)$. Mayoritas ODGJ memiliki jenis kelamin laki-laki sebanyak 10 orang $(55,6 \%)$, beragama Islam sebanyak 12 orang $(66,7 \%)$, serta kebanyakan ODGJ dalam penelitian ini adalah berstatus kawin sebanyak 14 orang $(77,8 \%)$, mayoritas ODGJ pendidikan terakhirnya adalah sebanyak 12 orang (66,7\%), mayoritas ODGJ yang di rawat sebanyak 0-3 kali adalah 10 orang (55,6\%), mayoritas ODGJ dengan lama rawat 1-3 bulan adalah 12 orang $(66,7 \%)$ dan mayoritas ODGJ dengan lama sakit 1-5 tahun sebanyak 11 orang $(61,1 \%)$.

Tabel 1 Distribusi frekuensi dan persentase data demografi orang dengan gangguan jiwa di Medan Sunggal $(\mathbf{n}=18)$

\begin{tabular}{clrc}
\hline No & Karakteristik ODGJ & Frekuensi (f) & Persentase (\%) \\
\hline 1 & Usia & 8 & \\
& 20-40 tahun & 8 & 44,4 \\
& $40-60$ tahun & 2 & 44,4 \\
& $>80$ tahun & & 11,1 \\
\hline 2 & Jenis Kelamin & 10 & \\
& Laki-Laki & 8 & 55,6 \\
& Perempuan & & 44,4 \\
\hline 3 & Agama & 12 & \\
& Islam & 6 & 66,7 \\
& Kristen & & 33,3 \\
\hline 4 & Status Perkawinan & 14 & 77,8 \\
& Kawin & 3 & 16,7 \\
& Tidak Kawin & 1 & 5,6 \\
& Duda / Janda & & 16,7 \\
\hline 5 & Pendidikan Terakhir & 3 & 5,6 \\
& SD & 1 & \\
& SMP & &
\end{tabular}




\begin{tabular}{clrc}
\hline No & Karakteristik ODGJ & Frekuensi (f) & Persentase (\%) \\
\hline & SMA & 12 & 66,7 \\
& S1 & 2 & 11,1 \\
\hline 6 & Frekuensi Dirawat & 10 & \\
& $0-3$ kali & 5 & 55,6 \\
& $4-6$ kali & 3 & 27,8 \\
& $7-9$ kali & & 16,7 \\
\hline 7 & Lama Rawat & 12 & \\
& $0-3$ bulan & 0 & 66,7 \\
& $4-6$ bulan & 1 & 0 \\
& $7-9$ bulan & 5 & 5,6 \\
& $>10$ bulan & & 27.8 \\
\hline 8. & Lama Sakit & 11 & \\
& $1-5$ tahun & 6 & 61,1 \\
& $6-10$ tahun & 6 & 33,3 \\
& $11-15$ tahun & 1 & 5,6 \\
\hline
\end{tabular}

Hasil penelitian pada tabel 2 didapatkan hasilnya yaitu mayoritas ODGJ mendapatkan dukungan keluarga yang baik sebanyak 12 orang $(66,7 \%)$.

Tabel 2 Distribusi Frekuensi Pada Dukungan Keluarga ODGJ Di Medan Sunggal $(\mathbf{n}=18)$

\begin{tabular}{llrc}
\hline No & Dukungan Keluarga & Frekuensi (f) & Persentase (\%) \\
\hline 1 & Kurang & 0 & 0 \\
\hline 2 & Cukup & 6 & 33.3 \\
\hline 3 & Baik & 12 & 66,7 \\
\hline
\end{tabular}

Hasil penelitian pada tabel 3 menunjukkan mayoritas ODGJ membutuhkan peralatan atau alat bantu sebanyak 9 orang (50\%).

Tabel 3 Distribusi Frekuensi Pada Tingkat Kemampuan Perawatan Diri ODGJ Di Medan Sunggal $(\mathbf{n}=\mathbf{1 8})$

\begin{tabular}{clcc}
\hline No & Tingkat Kemampuan Perawatan diri & $\begin{array}{l}\text { Frekuensi } \\
\text { (f) }\end{array}$ & Persentase (\%) \\
\hline 1 & Mandiri Penuh & 0 & 0 \\
\hline 2 & Membutuhkan peralatan atau alat bantu & 9 & 50 \\
\hline 3 & $\begin{array}{l}\text { Membutuhkan pertolongan orang lain untuk bantuan, } \\
\text { pengawasan, pendidikan }\end{array}$ & 2 & 11,1 \\
\hline 4 & $\begin{array}{l}\text { Membutuhkan pertolongan orang lain dan } \\
\text { peralatan atau alat bantu }\end{array}$ & 5 & 11,1 \\
\hline 5 & $\begin{array}{l}\text { Ketergantungan, tidak dapat berpartisipasi dalam } \\
\text { aktivitas }\end{array}$ & 2 & \\
\hline
\end{tabular}

Hasil penelitian pada tabel 4 menunjukkan bahwa analisis hubungan dukungan keluarga dengan tingkat kemampuan perawatan diri orang dengan gangguan jiwa di Medan Sunggal dengan menggunakan uji Spearmen di peroleh nilai $p=0,03$. Angka ini lebih kecil dari pada nilai a (alpha) $=0,05$ sehingga terdapat hubungan antara dukungan keluarga dengan tingkat kemampuan perawatan diri pada orang dengan gangguan jiwa di Medan Sunggal. Dan nilai r sebesar 0,664 yang menunjukkan bahwa tingkat korelasi antara dukungan keluarga dengan tingkat kemampuan perawatan diri ODGJ adalah korelasi kuat. Sedangkan hubungan positif yang terdapat pada koefisien korelasi 
menunjukkan bahwa hubungan bersifat searah yang artinya semakin meningkat dukungan keluarga maka tingkat kemampuan perawatan diri ODGJ juga semakin meningkat.

Tabel 4 Hubungan Dukungan Keluarga Dengan Tingkat Kemampuan Perawatan Diri ODGJ Di Medan Sunggal (n=18)

\begin{tabular}{lllll}
\hline Variabel 1 & Variabel 2 & & $r$ & p value \\
\hline Dukungan Keluarga & Tingkat & Kemampuan & 0,664 & 0,03 \\
& Perawatan Diri & & \\
\hline Dukungan Keluarga & $\begin{array}{l}\text { Tingkat Kemampuan } \\
\text { Perawatan Diri }\end{array}$ & & 0,664 & 0,03 \\
& & & \\
\hline
\end{tabular}

\section{Pembahasan}

Berdasarkan hasil penelitian mengenai dukungan keluarga diketahui hasilnya adalah ODGJ yang mendapatkan dukungan keluarga yang cukup sebanyak 6 orang $(33,3 \%)$ sedangkan ODGJ yang mendapatkan dukungan keluarga yang baik sebanyak 12 orang $(66,7 \%)$. Hal ini sejalan dengan pendapat (Keliat, 2018) yang mengatakan bahwa Orang Dengan Gangguan Jiwa (ODGJ) yang mendapatkan dukungan tepat seperti dukungan emosional, dukungan informational, dukungan instrumental dan dukungan peniaian, dapat sembuh dari kondisi yang di alami dan mendapatkan kehidupan yang memuaskan serta produktif.

Angka dukungan keluarga memiliki nilai rata-rata 55,83, dengan nilai dukungan terendah adalah 24 dan nilai dukungan tertinggi adalah 72 (pada skala skor 0-72). Dari hasil ini dapat di katakan dukungan keluarga yang di terima oleh responden terbilang cukup besar pada rata-rata skala pengukuran tersebut. Hal ini juga sejalan dengan pendapat (Friedman, 2010) dimana hasil tersebut memperlihatkan masih berfungsinya keluarga klien ODGJ khususnya fungsi afektif sebagai fungsi internal keluarga untuk memenuhi semua kebutuhan psikososial anggota keluarga sebagai berikut: saling mengasuh, cinta kasih, kehangatan dan saling mendukung antar anggota keluarga.

Menurut Friedman, 2010 Dukungan keluarga yang di maksud diantaranya dukungan emosional, dukungan informasi, dukungan instrumental dan dukungan penilaian. Dukungan tersebut akan membentuk satu kesatuan dukungan keluarga khusunya bagi salah satu keluarga yang mempunyai masalah kesehatan seperti gangguan jiwa dengan melibatkan dukungan keluarga untuk meningkatkan kemampuan perawatan diri ODGJ, Hal ini juga sejalan dengan pendapat (Yusuf, Hanik, Miranti \& Fanni, 2017) dimana pada dukungan emosional dan penghargaan adalah sebuah keahlian keluarga guna untuk menyampaikan kepada pasien rasa nyaman, di sayangi dan di hargai dan pasien akan merasa seperti di perhatikan seperti jika pasien melakukan hal yang positif seperti mengerjakan pekerjaan rumah, menyapu halaman dan lain-lain dengan sendiri atau mandiri maka dukungan yang di berikan keluarga adalah berupa pujian ataupun hadiah yang di inginkan pasien, dan untuk dukungan fasilitas adalah kebisaan keluarga membantu pasien dalam hal biaya dalam memberikan 
pelayanan kesehatan dan pertolongan kemudahan akses, serta dukungan informasi merupakan kebisaan keluarga untuk mendorong meningkatkan pengetahuan dan penerimaan pasien dan mengingatkan pasien untuk selalu tepat waktu dalam meminum obat dan mengingatkan tentang hal yang bisa memperparah kondisinnya.

Hasil analisis tingkat kemampuan perawatan diri ODGJ di Medan Sunggal meliputi : mandi, berpakaian, makan dan eliminasi adalah tidak ada responden yang mandiri penuh sedangkan membutuhkan peralatan atau alat bantu sebanyak 9 orang (50\%), responden yang membutuhkan pertolongan orang lain untuk bantuan, pengawasan, pendidikan sebanyak 2 orang $(11,1 \%)$, responden yang membutuhkan pertolongan orang lain dan peralatan atau alat bantu sebanyak 5 orang $(27,8 \%)$ dan responden yang ketergantungan, tidak dapat berpartisipasi dalam aktivitas 2 orang $(11,1 \%)$. Mayoritas responden sebanyak 9 orang $(50 \%)$ membutuhkan peralatan atau alat bantu dan tidak ada responden yang mandiri penuh. Hal ini sejalan dengan pendapat Sundari (2019) Perilaku kemampuan perawatan diri klien orang dengan gangguan jiwa merupakan beberapa cukup atau bisa dalam melaksanakan perawatan dirinya tetapi masih tetap dengan bantuan atau dukungan dari keluarga yang merawat.

Hal seperti ini bisa dikarenakan keadaan klien yang masih memiliki gejala negatif ataupun positif skizofrenia contohnya halusinasi, memiliki pemikirian atau wawasan yang tidak menentu, ketidakperduliannya terhadap seseorang, aktivitas, peristiwa, dan bahkan lebih sedikit berbicara, merasa tidak senang atau bahagia dalam menjalani kehidupan, kehilangan atau tidak memiliki motivasi atau tidak memiliki kemauan dan dukungan untuk bertindak, menarik diri dari lingkungan (Hidayati, 2017). Dari penelitian yang telah di lakukan maka adapun hasil dari penelitian yang berjudul Hubungan Dukungan Keluarga Dengan Tingkat Kemampuan Perawatan Diri Orang Dengan Gangguan Jiwa Di Medan Sunggal dengan sampel sebanyak 18 orang dan kebanyakan dari sampel tersebut mendapatkan dukungan keluarga yang baik, dan hadil yang di uji melalui uji Spearman adalah terdapat hubungan antara dukungan keluarga dengan tingkat kemampuan perawatan diri ODGJ Di Medan Sunggal dengan mendapatkan nilai $p=0,03$ dimana lebih kecil dari nilai a (alpha) yaitu 0,05 dan nilai $r$ sebesar 0,664 yang menunjukkan bahwa tingkat korelasi antara dukungan keluarga dengan tingkat kemampuan perawatan diri ODGJ adalah korelasi kuat. Serta hubungan positif yang terdapat pada koefisien korelasi menunjukkan bahwa hubungan bersifat searah ataupun $\mathrm{H} 1$ diterima yang berarti ada hubungan yang bermakna (signifikan) antara dukungan keluarga dengan tingkat kemampuan perawatan diri ODGJ di Medan Sunggal, sehingga dapat di artikan semakin meningkat dukungan keluarga maka tingkat kemampuan perawatan diri ODGJ juga semakin meningkat, begitu juga sebaliknya jika dukungan keluarga nya tidak baik maka tingkat kemampuan perawatan diri juga akan menurun. Dan didukung dari penelitian yang di lakukan oleh (Sundari, 2019) yang hampir seluruh responden nya memiliki dukungan keluarga yang baik, sehingga dapat di artikan semakin tinggi dukungan yang di dapatkan oleh ODGJ maka semakin tinggi pula kemampuan perawatan pada ODGJ. Dan sejalan pula dengan pendapat dari (Arfandi , Z.; Susilo, E.; Widodo, 2013) yang mengatakan bahwa Keluarga adalah sekelompok orang yang paling dekat yang bisa memberikan suatu dampak positif untuk keluarga lainnya 
Menurut (MuhithA., 2015) dukungan keluarga yang diberikan dengan baik makan akan bisa menambah kemampuan perawatan diri pasien, begitupun sebaliknya, perawatan diri tidak bisa terpenuhi dengan maksimal jika tidak adanya keperdulian dan dukungan dari suatu keluarga.

Pada hasil penelitian ini sejalan dengan hasil penelitian yang dilakukan oleh (Livana et al, 2018) yang berjudul Dukungan Keluarga Dengan Perawatan Diri Pada Pasien Gangguan Jiwa Di Poli Jiwa dimana didapatkan hasilnya yaitu dukungan keluarga yang baik dan perawatan diri yang baik sebanyak $71(49,0 \%)$ dengan didapatkan hasil tersebut maka sejalan dengan pendapatnya bahwa hal tersebut terjadi karena keluarga mendapatkan dukungan yang baik meliputi dukungan emosional seperti semua keluh kesah pasien di dengarkan dengan baik oleh keluarga, keluarga juga memberikan keyakinan kepada pasien bahwasanya pasien akan sembuh, serta menjaga perasaan pasien, sedangkan dukungan penghargaan terpenuhi karena keluarga senantiasa selalu mengigatkan klien untuk minum obat dengan tepat waktu dan teratur, dan keluarga juga sering mengigatkan pasien control ke poli dan menanyakan kepada pasien jika ada masalah yang di hadapi oleh pasien, sedangkan dukungan materi meliputi keluarga memfasilitasi duit untuk biaya pengobatan pasien serta keluarga selalu menemani pasien dan membantu pasien jika terdapat kesulitan yang dialami oleh pasien selama di rumah dan dukungan informasi yang diberikan seperti keluarga memberitahu jika mandi selalu menggunakan sabun, lalu keluarga mengajak pasien untuk memakai baju dan mengingatkan setelah mandi maka badan di keringkan dengan menggunakan handuk, sehingga pasien yang mendapatkan dukungan keluarga yang baik maka kemampuan perawatan dirinya juga akan meningkan dengan baik.

\section{Kesimpulan}

Hasil penelitian menunjukkan bahwa analisis hubungan dukungan keluarga dengan tingkat kemampuan perawatan diri orang dengan gangguan jiwa di Medan Sunggal dengan menggunakan uji Spearmen di peroleh nilai $p=0,03$. Angka ini lebih kecil dari pada nilai a (alpha) $=0,05$ sehingga terdapat hubungan antara dukungan keluarga dengan tingkat kemampuan perawatan diri pada orang dengan gangguan jiwa di Medan Sunggal. Dan nilai $r$ sebesar 0,664 yang menunjukkan bahwa tingkat korelasi antara dukungan keluarga dengan tingkat kemampuan perawatan diri ODGJ adalah korelasi kuat. Sedangkan hubungan positif yang terdapat pada koefisien korelasi menunjukkan bahwa hubungan bersifat searah yang artinya semakin meningkat dukungan keluarga maka tingkat kemampuan perawatan diri ODGJ juga semakin meningkat.

\section{Referensi}

Arfandi , Z.; Susilo, E.; Widodo, G. G. (2013). Hubungan Antara Dukungan Sosial Keluarga Dengan Kemampuan Perawatan Diri Pada Anak Retardasi Mental Di Slb Negeri Ungaran.

Arris, D. S. (2018). Hubungan Dukungan Keluarga Dengan Kemandirian Perawatan Diri Pasien Skizofrenia Di Kecamatan Geger Kabupaten Madiun (Doctoral Dissertation, Stikes Bhakti Husada Mulia). 
Badan Penelitian dan Pengembangan Kesehatan. 2010. Riset Kesehatan Dasar (Riskesdas 2010). [serial online]. www.litbang.depkes.go.id/...riskesdas2010/Laporan_riskesdas_2010.pdf. [5 Januari 2020].

Depkes RI. (2019). Riset Kesehatan Dasar 2018. Jakarta. Badan Penelitian dan Pengembangan Kesehatan Republik Indonesia.

Friedman, M.M., Bowden, O \& Jones, M.(2010). Buku ajar keperawatan JPNN. (2015). Penderita gangguan jiwa terus naik, jpnn.com . www.jpnn.com (diakses pada tanggal 5 Januari 2020).

Lestari, W. L. \& Wardhani, Y.F. 2014. Stigma dan Penanganan Penderita Gangguan Jiwa Berat yang Dipasung. Buletin Penelitian Sistem Kesehatan. Vol 17 (2) : 157 $: 166$

Marfuah, D., Noviyanti, RD. 2017. Kemampuan Keluarga Merawat Pasien Skizofrenia Dengan Gejala Halusinasi. The 6th University Research Colloquium 2017, Universitas Muhammadiyah Magelang.

Muhith, A. (2015). Pendidikan Keperawatan Jiwa (Teori dan Aplikasi). Yogyakarta: Andi.

Sundari, R. H., Azizah, L. M. R., \& Triwibowo, H. (2019). Hubungan Dukungan Keluarga Dengan Kemampuan Perawatan Diri (Self-Care agency) pada pasien skizofrenia di Wilayah Kerja Puskesmas Gedongan Kota Mojokerto.

Undang-Undang Kesehatan Jiwa. 2014. Undang-Undang Republik Indonesia Nomor 18 Tahun 2014 Tentang Kesehatan Jiwa. Jakarta: Presiden Republik Indonesia.

Yusuf, Ah, Hanik Endang N, Miranti Lorencia I, Fanni Okviasanti. 2017. Kebutuhan Spiritual: Konsep dan Aplikasi Dalam Asuhan Keperawatan

PH, L., Hermanto, H., \& Pratama, N. (2018). Dukungan Keluarga dengan Perawatan Diri pada Pasein Gangguan Jiwa di Poli Jiwa. Jurnal Kesehatan Manarang, 4(1), 11-17. 